\title{
Hubungan Antara Faktor Sosiodemografi Dengan Tingkat Pengetahuan Dalam Swamedikasi Analgesik Oral Terhadap Pasien Dengan Keluhan Nyeri Gigi Di Beberapa Apotek Kota Malang
}

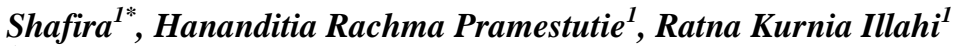

${ }^{I}$ Program Studi Sarjana Farmasi, Fakultas Kedokteran, Universitas Brawijaya, Malang Indonesia

INFO

ARTIKEL

$\overline{\text { Sejarah artikel: }}$

Penerimaan

naskah: 8

September 2019

Penerimaan

naskah revisi:

21 Januari 2020

Disetujui untuk

dipublikasikan:

25 Januari 2021

\section{Kata kunci :}

Tingkat pengetahuan,

Sosiodemografi,

Analgesik,

Nyeri Gigi

\begin{abstract}
A B S T R A K
Rasa nyeri gigi timbul ditandai dengan adanya kerusakan pada struktur gigi. Obat analgesik dapat digunakan untuk mengurangi nyeri akibat sakit gigi. Sebagian besar obat analgesik memiliki efek samping gangguan pada lambung jika digunakan secara tidak tepat. Diperlukan pengetahuan yang baik terkait penggunaan analgesik untuk nyeri gigi agar pengobatan dapat tepat. Penelitian ini bertujuan untuk mengetahui hubungan antara faktor sosiodemografi dengan tingkat pengetahuan seseorang mengenai swamedikasi analgesik oral dalam mengatasi keluhan nyeri gigi. Penelitian ini merupakan penelitian observasional analitik dengan metode cross sectional. Sampel dalam penelitian ini adalah pasien yang melakukan swamedikasi analgesik oral untuk nyeri gigi di Apotek Kota Malang yang terpilih secara purposive sampling sesuai kriteria inklusi dan eksklusi. Jumlah responden yang didapatkan sebanyak 100 responden. Instrumen yang digunakan dalam penelitian berupa kuesioner pengetahuan yang telah diuji validitas dan reabilitasnya. Uji Somers'd dan Kruskal Wills digunakan sebagai analisis statistik guna mengetahui hubungan faktor sosiodemografi dengan tingkat pengetahuan dalam swamedikasi nyeri gigi. Hasil penelitian menunjukan bahwa tingkat pengetahuan masyarakat Kota Malang yang melakukan swamedikasi analgesik oral terbanyak kategori cukup sebesar (37\%), kurang (32\%), dan baik (31\%), serta hasil menunjukkan adanya hubungan signifikan pada usia $(\mathrm{p}=0.005)$ dan pendidikan $(0.000)$. Sehingga dapat disimpulkan bahwa tidak semua faktor sosiodemografi berpengaruh dalam tingkat pengetahuan mengenai analgesik oral dimana hanya faktor usia dan tingkat pendidikan yang berpengaruh terhadap pengetahuan seseorang dalam melakukan swamedikasi analgesik oral untuk mengatasi keluhan nyeri gigi.
\end{abstract}

Correlation Between Sociodemographic Factors and Knowledge Levels In Self-Medication Of Oral Analgesics In Dental Pain Patients In Several Pharmacies In Malang.

Keywords:

Level of

knowledge,

Socio-

demograpics,

Analgesics,

Dental Pain

\section{A B S T R A C T}

Tooth pain is characterized by the tooth structure damage. Analgesic can be used to reduce pain during toothache. Analgesic have abdominal pain side effect if it is used inappropriately. Adequate knowledge of the anagesics used is needed for appropriate treatment. The aim of this study is to determine the correlation between socio-demographic factors and the level of one's knowledge about self-medication oral analgesics in dealing with complaints of dental pain. This study was an observational analytic study with a cross sectional method. Sample of this study is respondence who buy analgesic oral for toothache in pharmacies which sre selected using purposive sampling technique in accordance with the inclusion and exclusion criteria. The numbers of the obtained respondents are 100 respondents. The used instrument was a questionnaire to measure the level of knowledge of repondents that had been tested for validity and reability. The Somers' and Kruskal Wills tests were used as statistical analyzes to determine the relationship of socio-demographic factors with the level of knowledge in self-medication of tooth pain. The results showed that the level of knowledge of Malang City inhabitants who carried out selfmedication for analgesics was sufficent (37\%), less (32\%), and good (31\%), and there was a significant relationship between age $(\mathrm{p}=0.005)$ and education $(0,000)$ with the ac. Thus it can be concluded that not all socio-demographic factors have a significant correlation with the level of knowledge about oral analgesics, only age and education factors that influence the respondents who self-administered oral analgesics in dealing with complaints of dental pain. 


\section{Pendahuluan}

Swamedikasi adalah suatu upaya seseorang dalam memperoleh pengobatan untuk mengatasi keluhan yang dialaminya tanpa menggunakan resep dari dokter dan biasa ditujukan untuk mengatasi penyakit ringan seperti nyeri, demam, flu, batuk, nyeri lambung, dan nyeri punggung. Berbagai penelitian menunjukkan bahwa analgesik merupakan salah satu obat yang banyak digunakan secara swamedikasi $(36,2-59 \%)$ NSAID (Non Steroid Anti Inflammatory Drugs) merupakan jenis analgesik yang umum digunakan dan golongan NSAID yang banyak diswamedikasi adalah asam mefenamat $(28,44 \%)$ dan kalium diklofenak $(12,89 \%)^{1}$.

Terdapat penelitian yang dilakukan oleh Afif pada tahun 2015 di Kabupaten Demak, Jawa Tengah mengenai Hubungan Tingkat Pengetahuan dengan Ketepatan Penggunaan Obat Analgetik pada Swamedikasi Nyeri di Masyarakat Kabupaten Demak, pada uji tingkat pengetahuan dilakukan dengan memberikan kuesioner dan ketepatan penggunaan swamedikasi nyeri mencakup 4 kriteria, tepat golongan, tepat obat, tepat dosis, dan tepat waktu. Swamedikasi dikatakan tepat jika memenuhi semua kriteria, jika salah satu kriteria tidak terpenuhi maka swamedikasi yang dilakukan dinilai tidak tepat. Data menunjukkan dari 246 responden yang terkumpul, diperoleh nilai rata-rata tingkat pengetahuan sebesar 12,58 $\pm 2,00$ yang masuk dalam kategori cukup dan didapatkan $54 \%$ responden melakukan swamedikasi secara tidak tepat ${ }^{2}$. Penelitian ini dilakukan untuk meneliti hubungan pengetahuan swamedikasi dengan faktor yang lebih luas yakni dari faktor sosiodemografi yang meliputi usia, jenis kelamin, pekerjaan, penghasilan dan pendidikan dalam swamedikasi analgesik oral terhadap pasien dengan keluhan nyeri gigi di beberapa Apotek Kota Malang.

Hal ini dilakukan untuk memberikan informasi mengenai pentingnya ilmu pengetahuan dalam hal pengobatan seseorang dalam mengatasi keluhan nyeri gigi agar pengobatan yang dilakukan sesuai serta memperoleh manfaat yang diinginkan. Penelitian dilakukan di apotek karena apotek merupakan sarana pelayanan kefarmasian yang melayani swamedikasi dengan disertai pemberian konseling, informasi, dan edukasi oleh apoteker.

\section{Metode}

Penelitian ini dilakukan pada bulan April hingga Juni 2019 di apotek wilayah Kota Malang. Penelitian ini telah mendapatkan surat keterangan kelaikan etik (Ethical Clearance) No. 120 / EC / KEPK-S1Farm / 04/2019.

Sampel dalam penelitian ini adalah pasien yang melakukan swamedikasi analgesik oral di Apotek Kota Malang. Pengambilan sampel responden pada penelitian ini menggunakan teknik purposive sampling berdasarkan kriteria inklusi dan eksklusi yang telah ditentukan. Instrumen yang digunakan berupa kuesioner pengetahuan yang dirancang oleh peneliti dan telah diuji validitas serta reliabiltas. Kuesioner terdiri dari 10 butir pernyataan dengan pilihan jawaban benar dan salah mengenai penggunaan analgesik oral untuk nyeri gigi meliputi indikasi obat, kontraindikasi obat, dosis, cara pakai, interaksi, efek samping obat serta cara penyimpanan dan pembuangan.

Responden yang diperlukan dalam melakukan uji validitas dan reliabilitas yaitu sebanyak 30 responden. Pada penelitian ini, data hasil penelitian yang terkumpul dilakukan uji normalitas. Uji normalitas yang digunakan adalah Kolmogorov-Smirnov test. Uji normalitas berfungsi untuk mengukur apakah data yang digunakan memiliki distribusi yang normal atau tidak untuk menentukan penelitian termasuk penelitian parametrik atau non parametrik.

Uji yang digunakan untuk mengetahui hubungan antara faktor sosiodemografi terhadap tingkat pengetahuan mengenai swamedikasi analgesikoral yaitu uji Somers's dan Kruskal Wills. Kategori baik apabila nilai persentase 76-

$100 \%$, kategori cukup apabila nilai persentase $60-75 \%$, dan kategori kurang apabila nilai persentase $<60 \%$.

\section{Hasil dan Diskusi}

Sampel yang diperoleh dalam penelitian ini sebanyak 100 responden. Pada penelitian ini didapatkan data karakteristik sosiodemografi sebagai berikut
Tabel 1. Karakteristik Sosiodemografi Responden.

\begin{tabular}{|c|c|c|c|}
\hline Parameter & Kategori & $\begin{array}{c}\text { Jumlah } \\
\text { (n) }\end{array}$ & $\begin{array}{c}\text { Persentase } \\
(\%)\end{array}$ \\
\hline \multirow{3}{*}{ Usia } & $18-25$ tahun & 29 & 29,0 \\
\hline & $25-60$ tahun & 63 & 63,0 \\
\hline & $>60$ tahun & 8 & 8,0 \\
\hline \multirow{2}{*}{$\begin{array}{c}\text { Jenis } \\
\text { Kelamin }\end{array}$} & Laki-Laki & 40 & 40,0 \\
\hline & Perempuan & 60 & 60,0 \\
\hline \multirow{3}{*}{$\begin{array}{c}\text { Pendidikan } \\
\text { Terakhir }\end{array}$} & SD & 2 & 2,0 \\
\hline & SMP & 6 & 6,0 \\
\hline & SMA & 70 & $\mathbf{7 0 , 0}$ \\
\hline \multirow{3}{*}{$\begin{array}{c}\text { Tingkat } \\
\text { Penghasilan }\end{array}$} & $\begin{array}{c}\text { Rendah }(<3 \\
\text { juta) }\end{array}$ & 70 & 70,0 \\
\hline & $\begin{array}{c}\text { Sedang (3-5 } \\
\text { juta) }\end{array}$ & 21 & 21,0 \\
\hline & $\begin{array}{c}\text { Tinggi (>5 } \\
\text { juta) }\end{array}$ & 9 & 9,0 \\
\hline \multirow{7}{*}{ Pekerjaan } & $\begin{array}{c}\text { Pegawai } \\
\text { Swasta }\end{array}$ & 35 & 35,0 \\
\hline & $\begin{array}{c}\text { Ibu Rumah } \\
\text { Tangga }\end{array}$ & 23 & 23,0 \\
\hline & Wiraswasta & 28 & 28,0 \\
\hline & Kurir & 1 & 1,0 \\
\hline & Mahasiswa & 11 & 11,0 \\
\hline & $\begin{array}{c}\text { Tidak } \\
\text { Bekerja } \\
\end{array}$ & 1 & 1,0 \\
\hline & Pensiunan & 1 & 1,0 \\
\hline
\end{tabular}

Tabel 2. Karakteristik Pengetahuan Responden dalam Swamedikasi Nyeri Gigi

\begin{tabular}{ccc}
\hline Sumber informasi & $\begin{array}{c}\text { Frekuensi } \\
(\mathbf{n})\end{array}$ & Persentase (\%) \\
\hline Teman & 22 & 22,0 \\
\hline Keluarga & 31 & 31,0 \\
\hline Dokter & 16 & 16,0 \\
\hline Apoteker & 8 & 8,0 \\
\hline Tetangga & 10 & 10,0 \\
\hline $\begin{array}{c}\text { Tidak pernah } \\
\text { mendapatkan } \\
\text { informasi }\end{array}$ & 13 & 13,0 \\
\hline Total & 100 & 100,0 \\
\hline
\end{tabular}

Tabel 3. Sumber Informasi Swamedikasi

\begin{tabular}{|c|c|c|c|}
\hline Parameter & Kategori & Jumlah (n) & $\begin{array}{l}\text { Persentase } \\
(\%)\end{array}$ \\
\hline \multirow[t]{2}{*}{$\begin{array}{l}\text { Frekuensi } \\
\text { Keluhan }\end{array}$} & $\begin{array}{c}\text { Sering } \\
\text { (Lebih dari } 3 \\
\text { kali) }\end{array}$ & 38 & 38,0 \\
\hline & $\begin{array}{c}\text { Jarang (1- } \\
\text { 3kali) }\end{array}$ & 62 & 62,0 \\
\hline \multirow{3}{*}{$\begin{array}{l}\text { Periode } \\
\text { timbul } \\
\text { keluhan }\end{array}$} & $\begin{array}{c}\text { 1-3 bulan } \\
\text { lalu }\end{array}$ & 40 & 40,0 \\
\hline & $\begin{array}{l}3-6 \text { bulan } \\
\text { lalu }\end{array}$ & 23 & 23,0 \\
\hline & $\begin{array}{c}\text { Lebih dari } 6 \\
\text { bulan lalu }\end{array}$ & 28 & 28,0 \\
\hline \multirow{3}{*}{$\begin{array}{l}\text { Tindakan } \\
\text { yang } \\
\text { dilakukan }\end{array}$} & $\begin{array}{c}\text { Berobat ke } \\
\text { dokter }\end{array}$ & 8 & 8,0 \\
\hline & $\begin{array}{c}\text { Membeli } \\
\text { obat ke } \\
\text { apotek }\end{array}$ & 63 & 63,0 \\
\hline & $\begin{array}{c}\text { Pernah } \\
\text { melakukan } \\
\text { keduanya }\end{array}$ & 29 & 29,0 \\
\hline \multirow[t]{3}{*}{ Penyebab } & $\begin{array}{c}\text { Hilangnya } \\
\text { gusi }\end{array}$ & 4 & 4,0 \\
\hline & $\begin{array}{c}\text { Rasa ngilu } \\
\text { sehabis } \\
\text { makan atau } \\
\text { gigi } \\
\text { berlubang } \\
\end{array}$ & 85 & $\mathbf{8 5 , 0}$ \\
\hline & $\begin{array}{c}\text { Pernah } \\
\text { mengalami } \\
\text { keduanya }\end{array}$ & 11 & 11,0 \\
\hline
\end{tabular}


Tabel 4. Jenis Obat Swamedikasi Nyeri Gigi

\begin{tabular}{ccc}
\hline Jenis obat & Frekuensi (n) & Persentase (\%) \\
\hline Asam Mefenamat & 47 & 47,0 \\
\hline Paracetamol & 23 & 23,0 \\
\hline Ibuprofen & 9 & 9,0 \\
\hline Na Diklofenak & 2 & 2,0 \\
\hline Ka Diklofenak & 15 & 15,0 \\
\hline Asetosal & 1 & 1,0 \\
\hline Total & 100 & 100,0 \\
\hline
\end{tabular}

Pada Tabel 2. 63\% responden dengan usia 25-60 tahun paling banyak melakukan swamedikasi. Kelompok usia merupakan usia produktif, apabila kesehatannya terganggu orang dewasa akan mengambil keputusan untuk melakukan pengobatan sendiri. Semakin bertambah usia akan mempengaruhi pola pikir seseorang sehingga pengetahuan tentang swamedikasi yang diperolehnya semakin baik. Hasil ini juga sejalan dengan penelitian lain mengenai swamedikasi analgesik dimana mayoritas pasien yang melakukan swamedikasi analgesik berada pada rentang usia dewasa (26-45 tahun) $)^{3}$

Sebanyak $70 \%$ responden dengan pendidikan terakhir SMA lebih banyak melakukan swamedikasi dibandingkan tingkat pendidikan lainnya. Seseorang dengan pendidikan lebih tinggi lebih sering melakukan swamedikasi secara rasional Hal ini dapat dikarenakan seseorang yang memiliki tingkat pendidikan lebih tinggi dapat berpikir sejauh mana keuntungan yang diberikan seseorang terhadap perkembangan orang lain menuju kearah suatu keinginan tertentu ${ }^{4}$. Hasil ini juga didukung dengan data statistic dari Badan Pusat Statistik Kota Malang, tercatat di tahun 2018 pendidikan SMA merupakan tingkat pendidikan yang paling banyak diselesaikan oleh masyarakat kota malang dibandingkan jenjang lainnya sebesar $33,45 \%{ }^{5}$

Pada jenis kelamin, 60\% responden tercatat melakukan swamedikasi lebih banyak ada pada perempuan. Hasil ini bisa diketahui bahwa perempuan lebih peduli dengan kesehatan. Wanita memiliki kecenderungan untuk melakukan swamedikasi 1,48 kali lebih sering dibandingkan pria ${ }^{6 .}$

Pekerjaan yang paling banyak melakukan swamedikasi analgesik oral untuk mengatasi keluhan nyeri gigi adalah responden yang memiliki pekerjaan sebagai pegawai swasta sebesar 35\%. Lingkungan seseorang dalam bekerja tidak menutup kemungkinan mempengaruhi pola pikir seseorang dalam mengambil keputusan dan juga pekerjaan dapat berrkaitan dengan status ekonomi, masyarakat dengan jenis pekerjaan yang memiliki penghasilan tinggi cenderung lebih mudah untuk memenuhi kebutuhan kesehatan dibandingkan dengan penghasilan yang rendah memungkinkan untuk berobat ke apotek dikarenakan biaya yang dikeluarkan tidak sebanyak apabla berobat ke dokter atau klinik jika mengalami gangguan kesehatan. Hasil ini juga selaras dengan data pada Badan Pusat Statistik Kota Malang (2018) yaitu jumlah jiwa yang bekerja sebagai pegawai swasta mendominasi yakni sebesar 428.851 jiwa sehingga dapat disimpulkan bahwa jenis pekerjaan pegawai swasta merupakan jenis pekerjaan paling banyak di kota Malang ${ }^{7}$. Diperoleh data sebanyak 59 responden $(59,0 \%)$ melakukan swamedikasi nyeri gigi sebanyak 1-3 kali dalam waktu 1 tahun terakhir. Hasil ini dapat dikarenakan dikatakan bahwa sebesar $62 \%$ responden mengatakan bahwa dirinya termasuk seseorang yang jarang mengalami keluhan nyeri gigi. Nyeri gigi yang dialami oleh sebagian besar responden hanya terjadi 1-3 kali dalam waktu yang lama 1 tahun terakhir, hal ini dikarenakan senantiasa menjaga dan menghindari faktor penyebabnya seperti hanya terjadi nyeri gigi jika karena makanan atau minuman dingin, cuaca dan lainnya. Swamedikasi memiliki keuntungan yang lebih banyak dibandingkan dengan berobat ke dokter jika dilakukan dengan benar. Tercatat sebanyak $63 \%$ responden yang melakukan mengatasi keluhan nyeri gigi dengan membeli obat ke apotek. Hasil ini juga berkaitan dengan rentang jumlah penghasilan yang masuk ke dalam kategori rendah dimana untuk memberikan pelayanan kesehatan mandiri terkait keluhan yang dirasa tidak terlalu berbahaya responden cenderung memilih melakukan swamedikasi dengan membeli obat ke apotek yang dirasa akan sembuh dalam waktu singkat. pengobatan sendiri atau swamedikasi diantara lain dilakukan bagi masyarakat yang memiliki keluhan ringan seperti nyeri kepala, punggung, sakit gigi lebih memilih melakukan swamedikasi dibandingkan berobat ke dokter.

Data menunjukkan informasi mengenai swamedikasi terbanyak berasal dari kalangan keluarga. Sumber informasi adalah segala sesuatu yang menjadi perantara dalam penyampaian informasi, merangsang pikiran dan kemampuan seseorang. Anti Inflamasi Non Steroid (AINS) di kalangan etnis arab dari 100 sampel yang diteliti dikatakan bahwa sumber informasi obat paling banyak diperoleh berasal dari keluarga dengan persentase sebesar 33\%. Hal ini dapat dikarenakan faktor kebudayaan dan kepercayaan serta pengalaman dari keluarga memiliki peranan tertentu dalam membangun kepercayaan terhadap seseorang terutama dalam berpikir atau berperilaku ${ }^{8}$

Asam Mefenamat merupakan jenis obat yang paling banyak 47\% (47 responden) diswamedikasi untuk mengatasi keluhan nyeri gigi. Asam Mefenamat merupakan golongan AINS (Anti Inflamasi Non Steroid) dimana memiliki mekanisme sebagai penghambat sintesis prostaglandin yang merupakan mediator inflamasi yang dapat menimbulkan rasa nyeri. Asam mefenamat secara umum diindikasikan untuk meredakan rasa nyeri ringan sampai sedang seperti nyeri kepala, nyeri gigi, nyeri karena trauma, nyeri otot dan nyeri pasca operasi ${ }^{9}$

Tabel 5. Hasil Kuisioner

\begin{tabular}{llcc}
\hline No & \multicolumn{1}{c}{ Pernyataan } & \multicolumn{2}{c}{ Jawaban } \\
\cline { 3 - 4 } & & $\begin{array}{c}\text { Benar } \\
(\mathbf{n}, \boldsymbol{\%})\end{array}$ & $\begin{array}{c}\text { Salah }(\mathbf{n}, \\
\mathbf{\%})\end{array}$ \\
\hline 1 & Obat analgesik dapat digunakan & 97 & 3 \\
& saat merasa nyeri & $(97,0)$ & $(3,0)$ \\
\hline 2 & $\begin{array}{l}\text { Obat analgesik boleh dikonsumsi } \\
\text { bagi pasien yang pernah }\end{array}$ & 60 & 40 \\
& $\begin{array}{l}\text { mengalami gatal-gatal pada kulit } \\
3\end{array}$ & & $(40,0)$ \\
\hline & $\begin{array}{l}\text { Obat analgesik dikonsumsi } \\
\text { sampai habis walau sudah tidak } \\
\text { mengalami nyeri gigi }\end{array}$ & $(87,0)$ & $(13,0)$ \\
\hline
\end{tabular}




\begin{tabular}{|c|c|c|c|}
\hline 4 & $\begin{array}{l}\text { Obat analgesik tersedia dalam } \\
\text { bentuk tablet/kaplet }\end{array}$ & $\begin{array}{c}95 \\
(95,0) \\
\end{array}$ & $\begin{array}{c}5 \\
(5,0) \\
\end{array}$ \\
\hline 5 & $\begin{array}{l}\text { Mengkonsumsi obat analgesik } \\
\text { bersamaan dengaan teh dapat } \\
\text { menurunkan efektivitas obat }\end{array}$ & $\begin{array}{c}41 \\
(41,0)\end{array}$ & $\begin{array}{c}59 \\
(59,0)\end{array}$ \\
\hline 6 & $\begin{array}{l}\text { Mual adalah efek samping yang } \\
\text { ditimbulkan dari penggunaan } \\
\text { obat analgesik oral }\end{array}$ & $\begin{array}{c}61 \\
(61,0)\end{array}$ & $\begin{array}{c}39 \\
(39,0)\end{array}$ \\
\hline 7 & $\begin{array}{l}\text { Obat analgesik disimpan di } \\
\text { kulkas }\end{array}$ & $\begin{array}{c}74 \\
(74,0) \\
\end{array}$ & $\begin{array}{c}26 \\
(26,0)\end{array}$ \\
\hline 8 & $\begin{array}{l}\text { Obat analgesik dibuang langsung } \\
\text { ke tempat sampah jika sudah } \\
\text { kadaluarsa }\end{array}$ & $\begin{array}{c}27 \\
(27,0)\end{array}$ & $\begin{array}{c}73 \\
(73,0)\end{array}$ \\
\hline 9 & $\begin{array}{lll}\text { Obat analgesik tidak } & \text { boleh } \\
\text { dikonsumsi lebih dari } 1 & \text { tablet } \\
\text { dalam waktu bersamaan } & \\
\end{array}$ & $\begin{array}{c}62 \\
(62,0)\end{array}$ & $\begin{array}{c}38 \\
(38,0)\end{array}$ \\
\hline 10 & $\begin{array}{l}\text { Obat analgesik aman diminum } \\
\text { bersama makan }\end{array}$ & $\begin{array}{c}80 \\
(80,0)\end{array}$ & $\begin{array}{c}20 \\
(20,0)\end{array}$ \\
\hline
\end{tabular}

Tabel 65. Tingkat Pengetahuan Responden

\begin{tabular}{cc}
\hline Tingkat Pengetahuan & Persentase (\%) \\
\hline Baik & 31,0 \\
\hline Cukup & 37,0 \\
\hline Kurang & 32,0 \\
\hline Total & 100 \\
\hline
\end{tabular}

Berdasarkan tabel 6. Responden yang melakukan swamedikasi analgesik oral tergolong pada kategori cukup. Hasil ini menunjukkan bahwa tingkat pengetahuan responden masih dapat ditingkatkan dengan peranan apoteker dalam tindakan konseling yang dapat diberikan dalam pasien atau responden yang melakukan swamedikasi. Diharapkan dengan semakin tinggi tingkat pengetahuan responden terhadap swamedikasi maka semakin baik masyarakat dalam melakukan swamedikasi sehingga semakin rendah terjadinya kesalahan pengobatan karena keterbatasan pengetahuan masyarakat akan obat dan penggunaannya.

Tabel 7. Korelasi Faktor Sosiodemografi terhadap Tingkat Pengetahuan Responden

\begin{tabular}{ccc}
\hline Nilai Sig. & Variabel Bebas & Keterangan \\
\hline 0.000 & Pendidikan & Signifikan \\
\hline 0.005 & Usia & Signifikan \\
\hline 0.059 & Pekerjaan & Tidak Signifikan \\
\hline 0.480 & Penghasilan & Tidak Signifikan \\
\hline 0.353 & Jenis Kelamin & Tidak Signifikan \\
\hline
\end{tabular}

Berdasarkan hasil uji korelasi yang dilakukan dengan Somers'd dan Kruskal Wallis, tidak semua faktor sosiodemografi memiliki pengaruh terhadap pengetahuan seseorang dalam swamedikasi analgesik. Hasil uji menunjukkan nilai signifikansi dibawah $(\mathrm{p}<0.05)$ pada usia dan pendidikan. Oleh karena itu, hanya usia dan pendidikan yang diketahui berpengaruh dalam tingkat pengetahuan seseorang. Pada penelitian yang dilakukan oleh Osemene dan Laminkra (2012) mengenai prevalensi swamedikasi didapat hasil bahwa pada tingkat kelas sarjana, prevalensi swamedikasi meningkat secara marginal dari siswa tahun pertama sampai tahun kelima. Sehingga dapat dikatakan bahwa semakin tinggi pendidikan seseorang pemahaman mengenai suatu hal dalam hal ini swamedikasi juga semakin baik ${ }^{10}$.

Hasil ini juga sejalan dengan penelitian lain yakni Tingkat Pengetahuan Pasien dalam Swamedikasi di tiga apotek Kota Panyabungan diketahui bahwa tingkat pengetahuan mempunyai hubungan dengan pendidikan terakhir dengan nilai sig. menunjukkan (nilai $\mathrm{p}=0,000)^{11}$.

Usia dewasa merupakan usia yang sering melakukan swamedikasi. Usia menjadi salah satu faktor yang mempengaruhi pengobatan serta pemilihan obat dalam swamedikasi. Bertambahnya usia seseorang menjadikan seseorang tersebut harus lebih berhati-hati dalam menggunakan obat, karena pada kondisi tersebut terdapat perubahan fisiologis serta kecenderungan memiliki komplikasi penyakit yang menyebabkan rentan mengalami masalah terkait penggunaan obat yang ditakutkan dapat menimbulkan efek samping ${ }^{12}$.

Apoteker sebagai tenaga kefarmasian memiliki peranan penting dalam memberikan informasi obat terkait swamedikasi yang dilakukan oleh pasien. Dengan adanya penelitian ini diharapkan data yang diberikan mengenai faktor sosiodemografi responden dan hubungannya dengan tingkat pengetahuan dalam swamedikasi analgesik oral khususnya untuk mengatasi keluhan nyeri gigi ini dapat dijadikan sebagai sumber informasi atau referensi tambahan bagi apoteker serta tenaga medis dalam melakukan kegiatan kefarmasian kepada pasien, memberikan edukasi serta pelayanan di apotek khususnya mengenai kegiatan swamedikasi baik Obat Bebas, Obat Bebas Terbatas maupun Obat Wajib Apotek dalam obatobatan analgesik oral.

\section{Daftar Pustaka}

1. Balbuena FR, Aranda AB, Figueras A. 2009. Self Medication in Older Urban Mexicans. Drugs Aging.(1):51-60.

2. Afif, A. 2015. Hubungan Tingkat Pengetahuan Dengan Ketepatan Penggunaan Obat Analgetik Pada Swamedikasi Nyeri Di Masyarakat Kabupaten Demak.Fakultas Farmasi : Universitas Muhammadiyah Surakarta

3. Halim, V.,Prayitno, Wibowo. 2018. Profil Swamedikasi Analgesik di Surabaya Jawa Timur. Jurnal Ilmu Kefarmasian Indonesia. Vol 16. No. 1. Hlm 86-93

4. Notoadmojo, S. 2007. Metode Pendidikan dan Perilaku Kesehatan. Jakarta : Cetakan 2. Rineka Cipta

5. Badan Pusat Statistik. 2018. Persentase Penduduk Usia 10 tahun ke atas di Kota Malang menurut pendidikan tertinggi yang ditamatkan, 22015-2018. Malang(online).https://malangkota.bps.go.id/statistica ble.html, diakses pada 21 Juni 2019

6. Miguel, A. 2008. Factors of self-medicated drug use among the Spanishadult population. Pharmacoepidemiol Drug Saf;17:193-9.

7. Badan Pusat Statistik. 2018. Jumlah Angkatan kerja, Penduduk bekerja, Pengangguran, TPAK dan TPT.Malang: Badan Pusat Statistik Kota Malang (online) 
https://malangkota.bps.go.id/statisticable.html, diakses pada 21 Juni 2019

8. Hantoro, T., Pristianty, L., Athiyah,U. Pengaruh Pengetahuan Terhadap Perilaku Swamedikasi Obat Anti-Inflamasi Nonsteroid (Ains) Oral Pada Etnis Arab Di Surabaya Jurnal Farmasi Komunitas Vol. 1, No. 2, (2014) 45-48

9. Balasubramanian,A dan Sumanth, A. 2010. Mefenamic Acid- Role as Antipyretic. INDIAN PEDIATRIC. Vol 47

10. Osemene, K.Lamikanra, A. 2012. A Study of the Prevalence of Self-Medication Practice among University Students in Southwestern Nigeria. Tropical Journal of Pharmaceutical Research. 11(4)

11. Harahap, N.,Khairunnisa, Tanuwijaya,J. 2017. Tingkat Pengetahuan Pasien dan Rasionalitas Swamedikasi di Tiga Apotek Kota Panyabungan. Jurnal Sains Farmasi \&Klinis 3(2). 186-192

12. Alaqeel, S., Abanmy,O. 2015. Counselling practices in communitypharmacies in Riyadh, Saudi Arabia:a cross-sectional study. BMC Health Services. 15 ; 557 